\title{
67. Çeviri göstergebilimi bağlamında bir özde çeviri örneği: The Clown and His Daughter ${ }^{1}$
}

\author{
Sündüz ÖZTÜRK KASAR 2
}

Halise GÜLMÜŞ SIRKINTI3

\begin{abstract}
APA: Öztürk Kasar, S.; Gülmüş Sırkıntı, H. (2021). Çeviri göstergebilimi bağlamında bir özde çeviri örneği: The Clown and His Daughter. RumeliDE Dil ve Edebiyat Araştırmaları Dergisi, (23), 1042-1057. DOI: 10.29000/rumelide.949995.
\end{abstract}

\section{$\ddot{\mathbf{O} z}$}

Türk edebiyatının önde gelen isimlerinden Halide Edib Adıvar, 1935 yılında İngiltere'de gönüllü sürgünde olduğu yıllarda The Clown and His Daughter başlıklı eserini İngilizce olarak kaleme alır. Söz konusu eser, Osmanlı Devleti’nin çöküş yıllarını hafız bir kızın başından geçen olaylar üzerinden anlatmakta; dolayısıyla dönemin yaşantısına, toplumsal yapısına, gelenek ve göreneklerine, kısacası Osmanlı ve Türk kültürüne yönelik göstergelerden oluşmaktadır. Oluşturulduğu dil bağlamı yani İngiliz dili, yansıttığı dil ve kültür bağlamından, Türk dili ve kültüründen farklı olan The Clown and His Daughter, İngiliz yazın dizgesinde her ne kadar özgün eser olarak yayımlanmış olsa da Osmanlı ve Türk kültürüne ait, İngilizlere uzak olan göstergeler İngilizceye aktarılırken zihinsel bir çeviri sürecinden geçirildikleri varsayılmaktadır. Bu yaklaşımla, bu çalışmada The Clown and His Daughter bir çeviri ürün olarak ele alınmakta ve Sündüz Öztürk Kasar'ın ortaya koyduğu "özde çeviri” kavramı odağında incelenmektedir. Bir özde çevirmen olarak Adıvar'ın zihinsel çeviri izleri, betimleyici bir yaklaşımla çeviri ürün üzerinde aranmaktadır. Eserin Türkçe çevirisi de aynı yıl Adıvar'ın kaleminden çıkmış ve Sinekli Bakkal başlı̆̆ı ile önce tefrika, daha sonra kitap olarak yayımlanmıştır. Çalışmamızda, "özde çeviri” olarak ele alınan The Clown and His Daughter, “öz çeviri” ve Öztürk Kasar’ın önerdiği “aslına çeviri” kavramları doğrultusunda ele alınan Sinekli Bakkal ile karşılaştırmalı olarak okunarak Adıvar'ın kendi kültürüne dair göstergeleri öteki konumundaki İngiliz okura nasıl aktardı̆̆ı, bu göstergeleri metin aslına dönerken nasıl şekillendirdiği ve farklı çeviri türlerinin ve farklı okur kitlelerinin Adıvar'ı nasıl yönlendirdiği betimleyici bir yaklaşımla irdelenmektedir.

Anahtar kelimeler: Edebiyat çevirisi, özde çeviri, aslına çeviri, çeviri göstergebilimi, The Clown and His Daughter

\section{A watermark translation within the scope of semiotics of translation: The Clown and His Daughter}

\footnotetext{
Abstract

Halide Edib Adıvar, one of the most prominent authors of Turkish literature, wrote her book The Clown and His Daughter in English, in 1935, when she was in voluntary exile in England. The

$1 \quad$ Bu makale, Halise Gülmüş Sırkıntı’nın Yıldız Teknik Üniversitesi Sosyal Bilimler Enstitüsü Diller ve Kültürlerarası Çeviribilim Doktora Programı’nda Prof. Dr. Sündüz Öztürk Kasar’ın danışmanlığında hazırladığı doktora tezinden üretilmiştir.

2 Prof. Dr., Yıldız Teknik Üniversitesi, Fen Edebiyat Fakültesi, Batı Dilleri ve Edebiyatı, Mütercim Tercümanlık (Fransızca) (İstanbul, Türkiye), sunduzkasar@gmail.com, ORCID ID: oooo-ooo1-9642-7073 [Araştırma makalesi, Makale kayit tarihi: 14.04.2021-kabul tarihi: 20.06.2021; DOI: 10.2900o/rumelide.949995]

3 Arş. Gör., Fatih Sultan Mehmet Vakıf Üniversitesi, Edebiyat Fakültesi, İngilizce Mütercim ve Tercümanlık Bölümü (İstanbul, Türkiye), halisegulmus@gmail.com, ORCID ID: oooo-0003-2158-3818

Adres | Address

RumeliDE Dil ve Edebiyat Araşttrmaları Dergisi $\quad$ RumeliDE Journal of Language and Literature Studies Osmanağa Mahallesi, Mürver Çiçeği Sokak, No:14/8 Osmanağa Mahallesi, Mürver Çiçeği Sokak, No:14/8

Kadıköy - İSTANBUL / TÜRKIYE 34714 Kadıköy - ISTANBUL / TURKEY 34714 e-posta: editor@rumelide.com e-mail: editor@rumelide.com,

tel: +90 505 7958124, +90 2167730616 phone: +90 505 7958124, +90 2167730616
} 
Clown and His Daughter tells the story of a hafiz girl living in the last years of Ottoman Empire. Therefore, it is full of signs about the daily life, social structure, traditions and customs of the period; in short, Ottoman and Turkish culture. It can be said that the language and culture in which the book was created is different from the language and culture it reflects. Although it was published as an original work in the British literary system, it is assumed that the signs of Ottoman and Turkish culture that are far from British were subjected to a mental translation process while being transferred. With this approach, in this study, The Clown and His Daughter is treated as a translation product and analyzed within the concept of "watermark translation" introduced by Sündüz Öztürk Kasar. The traces of Adıvar's mental translation are sought within the translation product with a descriptive approach. Adivar translated the book into Turkish herself in the same year and the book was published first as a serial novel and then as a book with the title of Sinekli Bakkal. In this article The Clown and His Daughter, which is considered as "watermark translation", is read in comparison with Sinekli Bakkal, which is discussed within the concepts of "self-translation" and Öztürk Kasar's concept of "retro-translation". How Edib conveys the signs of her own culture to the English reader, how the signs are shaped while the text returns to its original culture and how different types of translation and different readers directed Adivar are examined with a descriptive approach.

Keywords: Literary translation, watermark translation, retro-translation, semiotics of translation, The Clown and His Daughter

\section{Giriş}

Türk Edebiyatı'nın önde gelen isimlerinden Halide Edib Adıvar, $1882^{4}$ yılında, diğer bir deyişle Osmanlı Devleti'nin çöküş yllarında İstanbul, Beşiktaş'ta dünyaya gelmiş, çocukluğunu ve gençlik yıllarını bu buhranlı dönemde geçirmiştir. Osmanlı Devleti’nin içte ve dışta birçok problemle boğuştuğu bu zorlu zamanların yansımalarını Adıvar'ın eserlerinde görmek mümkündür. Çalışmaya konu olan The Clown and His Daughter (1935) başlıklı eser de Abdülhamit Dönemi'nde geçmekte ve Adıvar, eserde dönemin gerçeklerini kurgusal bir anlatı üzerinden okurlarıyla paylaşmaktadır.

Küçük yaşlarda annesini kaybeden Adıvar, babası Mehmet Edib Bey ve anneannesi Nakiye Hanım tarafından yetiştirilir (Çalışlar, 2010: 15). Adıvar'ın anneannesi ne kadar geleneksel bir kadınsa, babası da bir o kadar Batılı tarzda eğitimi ve yaşantıyı savunan bir adamdır (Adıvar, 2005: 37). Babası Adıvar'ı İngiliz usulünde yetiştirmeye çabalar, anneannesi ise Doğu'nun gelenek ve göreneklerini torununa öğretmek konusunda ısrarcıdır (Enginün, 2007: 31). Batılı tarzda eğitimi savunan Mehmet Edib Bey, kızının da bu tarz bir eğitim alabilmesi için hayatı boyunca çaba sarf eder. Öyle ki, İstanbul'da Batılı tarzda eğitim veren dönemin önemli kurumlarından olan Amerikan Kı Koleji'ne kızını kaydettirebilmek için Mehmet Edib Bey, kızının yaşını büyüttürmeyi dahi göze alır (Adıvar, 2013: 90). Adıvar'ın gerek karakteri gerekse edebi kişiliği üzerinde oldukça derin etkiler bırakan Amerikan Kız Koleji, Adıvar'da babasının temellerini attığı Batı tarzı düşünce ve yaşam biçiminin devamlılığını sağlamakla kalmaz, aynı zamanda sonraları İngiliz dilinde eser kaleme almasını sağlayacak kadar yabancı dilde hâkimiyet kazanmasına da katkıda bulunur.

Halide Edib Adıvar'ın doğum tarihi kimi kaynaklarda 1882, kimi kaynaklarda ise 1884 olarak belirtilmektedir. Bu çalışmada, Adıvar'ın İstanbul Üniversitesi'nde bulunan nüfus kâğıt sureti temel alınarak 1882 kabul edilmiştir (Enginün, 2007: 29).

RumeliDE Dil ve Edebiyat Araşttrmaları Dergisi Osmanağa Mahallesi, Mürver Çiçeği Sokak, No:14/8 Kadıköy - İSTANBUL / TÜRKIYE 34714 e-posta: editor@rumelide.com tel: +90 $5057958124,+90216773$ o 616
Address

RumeliDE Journal of Language and Literature Studies

Osmanağa Mahallesi, Mürver Çiçeği Sokak, No:14/8

Kadıköy - ISTANBUL / TURKEY 34714

e-mail: editor@rumelide.com,

phone: +90 505 7958124, +90 216773 o 616 
Aldığı eğitimin yanı sıra farklı ülkelerden yakın arkadaşlar edinen ve sık sık yurt dışı seyahatleri gerçekleştiren Adıvar’n İngiliz dilinde kitaplar kaleme alabilmesi şaşırtıcı değildir. Çalışmanın araştırma nesnesi olarak seçilen The Clown and His Daughter başlıklı eser, Adıvar'ın İngilizce olarak kaleme aldığı eserlerinden yalnızca biridir. Durakbaşa (2000: 174), Adıvar'ın kendi ana dilinden başka bir dilde eserler kaleme almasının "kendisi ile gerçeklik arasına mesafe koyma" isteğinden kaynaklandığını belirtse de dönemin şartları düşünüldüğünde Adıvar'ın İngiliz dilinde eser kaleme alacak kadar kendisini geliştirmiş olması çă̆ın çok ötesindedir. Yazar kimliğinin yanı sıra üretken bir çevirmen olan Adıvar, yalnızca İngilizceden Türkçeye eserler çevirmekle kalmamış kendi eserlerini çevirerek "öz çeviri”ler de ortaya koymuştur (Grutman, 2009: 257). Adıvar, İngilizce olarak kaleme aldığı The Clown and His Daughter'ı da kendisi Sinekli Bakkal başlığı ile Türkçeye çevirir ve eser, Haber Akşam Postası (11 İlkteşrin (Ekim) 1935- 24 Şubat 1936) başlıklı gazetede her gün tefrika edilir. Tefrikanın çok ses getirmesiyle eser, 1936 yllında Ahmet Halit kitabevi tarafından kitap olarak basılır ve kitap basımının ardından çok geçmeden 1942 yllında CHP roman ödülünü kazanır. Çalışma doğrultusunda Haber Akşam Postası başlıklı gazetede yayımlanan Sinekli Bakkal'ın tefrikalarına ulaşılmış, tefrikalar 1936 yılında kitap olarak basılan ve günümüze değin basımı devam eden kitap versiyonu ile karşlaştırılmıştır. Ancak eserin tefrika versiyonu ile kitap versiyonu arasında herhangi bir farklılığa, dolayısıyla diliçi çeviriye rastlanmamıştır.

The British Newspaper Archive üzerinden gerçekleştirilen araştırma sonucunda elde edilen The Clown and His Daughter başlıklı eser üzerine kaleme alınmış gazetelerdeki köşe yazıları incelenmiş ve eserin İngiliz okurlar tarafından oldukça ilgi gördüğü saptanmıştır. Eserin İngiliz toplumunun aşina olmadığı ve bu sebeple ilgilerini çekebilecek Osmanlı toplumunun yaşantısına, gelenek ve göreneklerine dair göstergelerle çevrelenmiş olduğu ve II. Abdülhamit rejiminin toplumsal, dini ve siyasi sorunlarına değindiği, kurgusal bir anlatı vasıtasıyla dönem tanıklığı yaptığı düşünüldüğünde yabancı basında ilgi görmüş olması şaşırtıcı değildir.

$\mathrm{Bu}$ çalışmada, The Clown and His Daughter üzerine kaleme alınmış diğer çalışmalardan (Arslan, 2006; Karadă \& Yalçındağ, 2020) farklı olarak The Clown and His Daughter ve Türkçe çevirisi Sinekli Bakkal Çeviri Göstergebilimi yaklaşımı ile irdelenmekte ve Sündüz Öztürk Kasar (2012; 2020) tarafından önerilen "özde çeviri” ve "aslına çeviri" kavramları doğrultusunda mercek altına alınmaktadır. Zihinsel bir çeviri sürecinden geçtiği varsayılan The Clown and His Daughter "özde çeviri” kavramı çerçevesinde incelenmekte, bir "çevirmen” olarak Adıvar'ın zihinsel çeviri sürecinde aldığı çeviri kararlarının çeviri metin üzerindeki yansımaları, "aslına çeviri” kavramı doğrultusunda ele alınan Sinekli Bakkal başlıklı eserle karşılaştırılarak okunmaktadır. Bu sayede, Osmanlı kültürüne ait göstergelerin zihinsel çeviri sürecinden geçerek İngilizceye nasıl aktarıldığı ve çıkış noktası olan Türkçeye nasıl geri döndüğü betimlenmeye çalışılmaktadır. Aynı zamanda farklı çeviri türleri söz konusu olduğunda çevirmenlerin üstlendikleri farklı sorumluluk ve misyonlar üzerinde durulmakta, okur farklılıklarının çevirmen üzerindeki etkisi tartışılmaktadır.

\section{2. Çeviri göstergebiliminden doğan yeni bir kavram: özde çeviri}

20. yüzyılın son çeyreğinde başlayan çalışmalarla Çeviribilim ve Göstergebilim alanları arasında ilişki kurulmaya başlanmış, ilk olarak Dinda L. Gorlee (1994) kaleme aldı $\breve{g}$ Semiotics and the Problem of Translation. With Special Reference to the Semiotics of Charles S. Peirce başlıklı eserde Charles S. Pierce'ün Göstergebilim yaklaşımından yola çıkarak Çeviri alanı ile birlikteliğine değinmiş, Gorleé’yi Peteer Torop’un (2000) çalışması izlemiştir. 
Türkiye'de ise Çeviribilim ve Göstergebilim alanlarının disiplinlerarası buluşma düzleminde çalışan Sündüz Öztürk Kasar (2001), eğitim aldığı Paris Göstergebilim Okulu’nun kurucularından JeanClaude Coquet'nin Göstergebilim bakış açısından yola çıarak ilk olarak "La sémiotique subjectale et la traduction" [Özne göstergebilimi ve çeviri] başlıklı bildirisinde iki bilim dalının birbirinden beslenebileceğini dile getirir. Öztürk Kasar (2020: 2) göstergebilimciyi de çevirmeni de bir "anlam avcısı” olarak tanımlar. Göstergebilimciler anlatıları çözümleyip, göstergeleri yorumlamak adına anlamın peşinden koşarken; çevirmenler her şeyden önce bir okur olarak göstergeleri kavrayarak, anlatının anlam evren evrenine ulaşmaya çalışırlar. Anlamın peşinden giden çevirmenleri yazınsal metinler söz konusu olduğunda çok daha zorlu bir görev beklemektedir çünkü yazınsal metin örtük göstergelerle, yananlamlarla ve tuzaklarla dolu olan "kaygan bir zemindir" (Öztürk Kasar, Tuna, 2015: 461). Yazınsal metinde anlam arayışına çıkan çevirmen tüm bu bulmacaları çözmek ve tuzaklara düşmemek adına bir yol göstericiye ihtiyaç duyacaktır ve bu durumdaki bir çevirmenin imdadına yetişen, "anlam arayışına ışık tutan" da göstergebilimin sunacağı çözümleme yöntemleridir (Öztürk Kasar, Tuna, 2015: 461).

Anlamın yakalanması ve yeniden oluşturulması konusuna odaklanan Çeviribilim ve Göstergebilim arasında kurulacak işbirliğinin "yazınsal çevirilerin niteliklerini artırmak adına kazanç” olacağını belirten Öztürk Kasar (2012), kaleme aldığı "Traduction de la ville sous le point de vue sémiotique: Istanbul à travers ses signes en trois langues” [“Göstergebilim Bakış Açısından Kent Çevirisi: Üç Dildeki Göstergelerin Anlatımıyla İstanbul”] başlıklı makalesinde Çeviribilim alanı için üç yeni kavram ileri sürer. Jason Goodwin'in 19. yy. İstanbul'unda geçen beş ciltlik polisiye roman dizisinin ilk kitabı olan ve Osmanlı'ya ve dönemin İstanbul'una dair göstergelerle örülü olmasına rağmen İngiliz dilinde kaleme alınmış Janissary Tree başlıklı anlatı üzerine çalışan Öztürk Kasar (2012), söz konusu eserden yola çıkarak Türkçede "özde çeviri" olarak kavramsallaştırdığı "traduction en filigrane" kavramını ortaya koyar. Özde çeviri, "yayınlanmış olduğu yerel dil bağlamında özgün metin olarak üretilmiş, ancak özünde zihinsel bir çeviri işleminin yer aldığı" ürünlere işaret etmektedir (Öztürk Kasar, 2020: 3). Diğer bir deyişle, önceleri özgün metin olarak görülen ancak yazıldığı dil ile kültür, yansıttı̆̆ dil ile kültürden farklı olan eserlerin artık zihinsel çeviri işlemleri içeren çeviri metin olarak görülebileceği, dolayısıyla böyle eserler kaleme alan yazarların da bir çevirmen olarak incelenebileceği görüşü (Öztürk Kasar, 2012) Çeviribilim alanına yeni bir bakış açısı getirmiştir.

Oluşturulduğu dilin uzamından farklı bir uzamda geçen ve farklı tarihsel ve toplumsal gerçekliklerle örülü olan özde çevirilerin okur tarafından çeviri olarak algılanması da şaşırtıcı olmayacaktır. Zira "özde çeviri" kavramı, Gideon Toury'nin (1995) ortaya koyduğu "sözde çeviri" kavramının ters köşesidir. Yayınlandığı dizgede çeviri gibi sunulan ancak herhangi bir kaynak metni bulunmayan eserleri Toury (1995:40), "sözde çeviri" olarak tanımlar. Bulunduğu edebi dizgede okurlara çeşitli çekincelerle çeviri olarak sunulmasına rağmen aslında bir kaynak metni olmayan, dolayısıyla özgün bir metin olan "sözde çeviriler"in tam tersi olarak "özde çeviriler" okurlara özgün metin olarak sunulmasına rağmen aslında alıcı kültürü ile aktarılan kültür birbirinden farklı olduğundan zihinsel bir çeviri işleminden geçmiş çeviri metinlerdir (Kasar, 2012).

Özde çeviri kavramından yola çıarak Çeviribilim alanına iki yeni kavram daha ortaya atan Öztürk Kasar (2020:7), bir çeviri olarak ele alınan özde çevirinin çıkış dili hariç diğer dillere yapılan çevirilerini "dolaylı özde çeviri" [Fr: traduction en filigrane indirecte] olarak adlandırmaktadır, yani bu çeviriler neredeyse ikinci dilden çevirilerdir. Özde çevirilerin çıkış dillerine yapılan çevirileri ise bir "aslına çeviri" [Fr: rétro-traduction] örneğidir, çünkü yabancı bir kitle için kaleme alınan özde çeviri eser çlkış dili ve kültürüne yani aslına geri dönmektedir (Öztürk Kasar, 2012: 268).

\begin{tabular}{r|l} 
Adres & Address \\
RumeliDE Dil ve Edebiyat Arastırmalart Dergisi & RumeliDE
\end{tabular}

Osmanağa Mahallesi, Mürver Çiçeği Sokak, No:14/8 Osmanağa Mahallesi, Mürver Çiçeği Sokak, No:14/8

Kadıköy - İSTANBUL / TÜRKIYE 34714 Kadıköy - ISTANBUL / TURKEY 34714

e-posta: editor@rumelide.com

tel: +90 505 7958124, +90 $2167730616 \quad \begin{aligned} & \text { e-mail: editor@rumelide.com, } \\ & \text { phone: +90 505 7958124, +90 } 2167730616\end{aligned}$ 
Özde çevirilerin iki farklı türü olduğunu belirten Öztürk Kasar (2020), bu iki türü öz bağlamdan yabancı bağlama giden özde çeviriler ve yabancı bağlamdan öz bağlama giden özde çeviriler olarak kavramsallaştırmıştır. Öz bağlamdan yabancı bağlama giden özde çeviriler söz konusu olduğunda, bu eserlerin genellikle yurt dışında yaşamakta olan ve ait oldukları ancak uzak kaldıkları kültürlerini ve değerlerini içinde bulundukları yabancı bağlama taşıyan çevirmenlere ait oldukları belirtilmektedir (Öztürk Kasar, 2020: 4). Çalışmaya konu olan Türk kültürü ve değerleriyle örülü The Clown and His Daughter bir Türk olan Halide Edib Adıvar tarafından İngiliz okur kitlesi için kaleme alındığından öz bağlamdan yabancı bağlama giden özde çevirilere örnek teşkil etmektedir ve Öztürk Kasar'ın tanımına uygun olarak eser Adıvar'ın yurt dışında gönüllü olarak sürgünde olduğu yıllarda, uzak kaldığı kendi kültürüne dair değerleri içinde yaşadığı İngiliz toplumuna aktarmak için kaleme aldığı bir özde çeviridir.

Yabancı bağlamdan öz bağlama giden özde çeviriler ise çevirmenlerin kendileriyle aynı kültürden gelenlere yabancıya ait gerçeklikleri anlatmak adına kaleme aldıkları özde çevirilere işaret etmektedir (Öztürk Kasar, 2020:5). "Yazarın Zihninde Bir Çeviri Edimi: Özde Çeviri Ürünü Olarak Kaynak Metin ve Aslına Çevirisi” başlıklı makalesinde Öztürk Kasar’ın yaklaşımından esinlenen Tuna (2020: 885), yabancı bağlamdan öz bağlama giden bir özde çeviriyi incelemekte, özde çevirmenin yabancı bir kültüre dair olguları kendi algısı doğrultusunda zihinsel çeviri işlemine tabi tutarak aktardığını ve özde çevirisinin "vardığı yargıların bir çıktısı" olduğunu vurgulamaktadır. Tuna ve Çelik (2021) kaleme aldıkları çalışmalarında Eric Ambler'in The Light of Day başlıklı yabancı bağlamdan öz bağlama giden özde çevirisini ve eserin Türkçe aslına çevirisini Çeviri Göstergebilimi yaklaşımıyla incelemişler ve aslına çevirmeni metne yaptığı müdahalelerden ötürü gizli ortak yazar (covert co-author) olarak tanımlamışlardır.

Öztürk Kasar (2020: 4), kâğıt para ışı̆̆a tutulduğunda görünür hale gelen filigran gibi, özde çevirilerin de detaylı bir şekilde incelendiklerinde çevirmenin zihinsel çeviri sürecinin çeviri metin üzerinde gözlemlenebilir olduğunu vurgular. Bu çalışmada The Clown and His Daughter başlıklı özgün metin olarak sunulan anlatı "özde çeviri” kavramı doğrultusunda kültürel göstergeler bağlamında incelenmekte ve çevirmenin zihinsel çeviri süreçleri saptanmaya çalışılmaktadır.

\subsection{Bir özde çeviri örneği: The Clown and His Daughter}

Halide Edib Adıvar, Osmanlı Devleti’nin çöküş yıllarını, Padişah II. Abdülhamit ile saray eşrafını ve dönemin toplumsal yaşantısını hafız bir başkarakterin üzerinden anlattığı The Clown and His Daughter başlıklı anlatıyı İngiltere'de gönüllü sürgünde olduğu 1935 yllında kaleme alır ve eser Londra'daki George Allen and Unwin yayınevi tarafından özgün bir eser olarak yayımlanır. Eserin Osmanlı kültürünü ve geleneklerini anlatması dolayısıyla yabancı basında oldukça ilgi çektiği yapılan incelemeler sonucunda gözlemlenmiştir.

Uzamı İstanbul'un arka mahallelerinden Sinekli Bakkal mahallesi olmakla birlikte, söz konusu mahalledeki halkın yaşantısının yanı sıra saray eşrafını da konu edinen anlatı, Osmanlı ve Türk kültürü ile örülüdür. Her ne kadar İngiltere'de İngilizce olarak yayımlansa da İngiliz okur için fazlasıyla uzak ve anlaşılması zor göstergeler içeren bu anlatı, özgün metin olarak sunulmuş olmasına rağmen okurlarında çeviri izlenimi yaratmaktadır. Öyle ki, Aberdeen Press and Journal (30 Kasım 1935) başlıklı gazetede "Bir Türk Kadın Yazarın Gözünden İstanbul” başlı̆̆ıyla yayımlanan köşe yazısında Adıvar'ın The Clown and His Daughter başlıklı eserinden bir çeviri olarak bahsedilmekte, ancak çevirmen adı bulunmadığı vurgulanmaktadır.

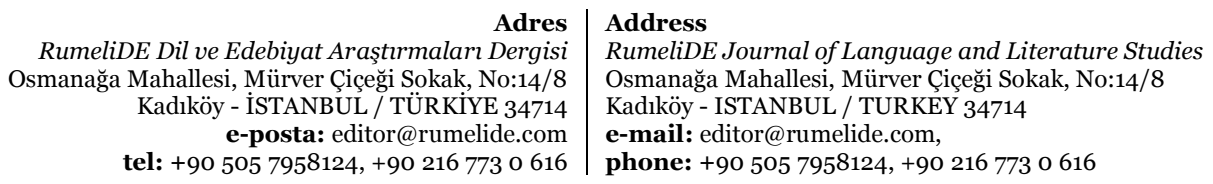


Sinekli Bakkal mahallesi imamının kızı Emine'nin Tevfik isimli bir orta oyuncu ile evlenmesiyle başlayan anlatı, kızları Rabia'nın hafız olmasıyla devam eder. The Clown and His Daughter'ın dönemin saray eşrafı ile halkın yaşantısı arasındaki farklar, İslami motifler, gölge oyunu, orta oyunu gibi yerel sanatlar başta olmak üzere Türk kültürüne ait unsurlarla bezenmiş bir metin olduğu söylenebilir. Orhan Burian Denemeler ve Eleştiriler başlıklı kitabında eserin Türk kültürüyle bezenmiş olduğu ve bu sebepten İngilizlerin ilgisini çektiğini şu sözlerle vurgular:

“... eser hem konu hem konuyu kontrol eden felsefe bakımından Türk’tür, İngiliz okurlarında da bunun için ilgi uyandırmıştır. Zaten bu roman için, yabancı bir okul kitlesi düşünülerek yazılmış demek doğru olur; onda bir hikâyeden çok, bir alem canlanmaktadır; Türk toplumunun tarihe geçmediği için bilinmeyen ama yabancılara bilgi verecek olan, özel yaşayışı.” (2004: 166)

Adıvar eserinde İngiliz okuru kendilerine kültürel ve toplumsal yaşantı açısından oldukça uzak olan Osmanlı Devleti'ne götürmekte ve burada İngiliz okuru imamlarla, hafızlarla, Mevlevilikle, karagöz oyunuyla tanıştırmaktadır. Adıvar'ın, İngiliz okurun kavram dünyasında bir karşılı̆̆ı olmayan Türk kültürüne ait tüm bu göstergeleri İngilizce olarak kaleme alırken, zihinsel bir çeviri sürecinden geçirmek durumunda kalmış olacağı düşünülmektedir. Bu sebepten çalışmada Adıvar bir "çevirmen" olarak ele alınmakta, betimleyici bir yaklaşımla zihinsel çeviri sürecinin metin üzerindeki izleri aranmaktadır.

\section{1. "Özde çeviri" ve "aslına çeviri" olarak inceleme metinleri}

Adıvar'ın zihnindeki kendi kültürüne ait göstergeleri öncelikle zihinsel olarak İngilizceye çevirerek aktardığı ve bir "özde çeviri” ortaya koyduğu varsayımından hareketle, özünde çeviri eylemi barındıran İngilizce eser Türkçeye çevrildiğinde bu eserin özüne yani aslına döndüğü söylenebilir. Bu açıdan bakıldığında The Clown and His Daughter'ın Türkçe çevirisi olan Sinekli Bakkal bir "aslına çeviri" örneği olarak ele alınabilir (Öztürk Kasar, 2012). Ancak bu çalışmaya konu edilen eserlerde durum biraz daha farklıdır. Öyle ki eseri ilk olarak İngiliz dilinde kaleme alan da sonrasında Türkçeye çeviren de Adıvar'dan başkası değildir. Bu doğrultuda bakıldığında, çeviri türlerinin zenginliği bir kez daha kendini göstermekte ve bir "aslına çeviri” örneği teşkil eden Sinekli Bakkal aynı zamanda bir "öz çeviri” (Grutman, 2009: 257) örneği olarak da dikkat çekmektedir. Sinekli Bakkal başlıklı eser bu çalışmada "aslına öz çeviri” olarak kavramsallaştırılmakta ve özde çevirideki zihinsel çeviri izlerinin okunmasında yardımcı metin olarak kullanılmaktadır. Adıvar'ın "özde çeviri” metindeki zihinsel çeviri eylemlerini daha somut bir şekilde görebilmek için, elde edilen zihinsel çeviri örnekleri, "aslına öz çeviri” metin ile karşılaştırmalı olarak incelenmekte, bu sayede Adıvar'ın İngiliz okurlar için kendi kültürünü aktarırken metne yaptığı müdahalelerin daha kolay anlaşılabileceği düşünülmektedir.

\section{3. Özde çeviride ve aslına öz çeviride kültürel göstergelerin aktarılması}

Her dilin kavram dünyası farklıdır ve dildeki tüm bu kavramlar belirli bir uzamda ve süreç içinde gerçeklik düzleminde var olurlar (Öztürk Kasar, 2020: 21). Süreç içinde söz konusu kültürün geçirdiği değişim ve dönüşümler dilde karşllı̆̆ını bulurken dildeki değişim ve dönüşümler de ilgili kültürü şekillendirir. Bu çalışmanın araştırma nesnesi olan The Clown and His Daughter gibi öz bağlamdan yabancı bağlama giden özde çeviriler söz konusu olduğunda, çevirmenin kendi kültürü ve diline ait olan kavram dünyasını yabancı bir okur kitlesine aktarması gerekmektedir. Fakat yıllarca içinde yaşadığı Türk kültürünü ve bu kültüre ait göstergeleri Türk kültürüne oldukça uzak bir kültüre sahip olan İngiliz(ce) okur kitlesine aktarmak, kavram dünyalarında bulunmayan olguları anlatmaya çalışmak çevirmen Adıvar için oldukça zorlu bir iştir. Adıvar'ın bu aktarım sürecinde en çok zorlandığı

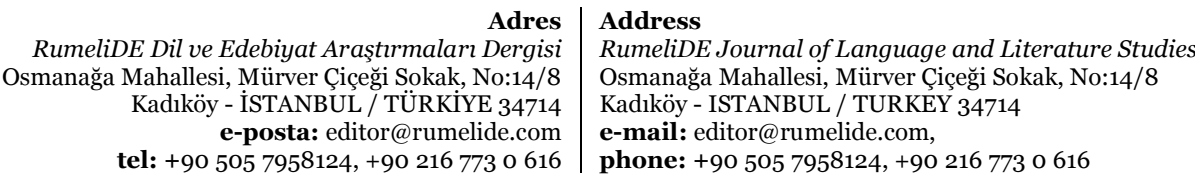


ve dolayısıyla zihinsel çeviri izlerinin çeviri metin üzerinde en somut şekilde gözlemlenebileceği düşünülen noktalar, Osmanlı-Türk kültürüne ve yaşantısına dair göstergelerdir. Bu nedenledir ki bu çalışmada özde çevirideki kültürel göstergelere odaklanılmakta, bu göstergelerin ilk olarak Adıvar'ın zihninde İngilizceye nasıl aktarıldığı, sonrasında ise Türkçeye nasıl geri döndürüldüğü irdelenmektedir.

The Clown and His Daughter başlıklı anlatı incelendiğinde anlatıdaki kültürel göstergelerin; dini göstergeler, deyim \& deyişler, yerel sanat, giysiler, yemek kültürü ve toplumsal yaşam olmak üzere altı başlık altında yoğunlaştığı gözlemlenmiştir. Bu doğrultuda gerçekleştirilen kültürel göstergeler sınıflandırması neticesinde, özde çeviri olarak ele alınan The Clown and His Daughter'dan ve aslına öz çeviri olarak ele alınan Sinekli Bakkal'dan elde edilen kesitler aşağıdaki örneklerde karşılaştırmalı olarak incelenmiştir.

\subsection{Dini göstergelerin aktarılması}

Çalışmaya konu edilen anlatılar incelendiğinde, İslam dinine ait göstergelerin yoğunlukta olduğu gözlemlenmiştir. İmam olan dedesinden aldığı eğitim sonucunda genç yaşta hafızlıkla geçimini sağlamaya başlayan Rabia'nın başkarakter olduğu bir anlatıda dini göstergelerin sıklıkla okurun karşısına çıkması şaşırtıcı değildir. Adıvar'ın The Clown and His Daughter'da sıklıkla karşılaşılan imam, hafiz, kandil gecesi, cuma namazı, mevlit gibi dini göstergeleri İngiliz okura aktarırken zorlandığı ve zihinsel çeviri işlemine başvurmak durumunda kaldığı görülmektedir. Aşă̆ıdaki iki örnekte dini göstergeler özde çeviri ve aslına öz çeviri karşılaştırılarak incelenmiştir.

\section{1. Örnek}

\begin{tabular}{|c|c|}
\hline $\begin{array}{l}\text { İnceleme } \\
\text { Metinleri }\end{array}$ & İncelenen Bağlam \\
\hline $\begin{array}{l}\text { Özde Çeviri } \\
\text { (Adıvar,1935: 117) }\end{array}$ & $\begin{array}{l}\text { His shows began with the traditional prayer } 5 \text { to His Majesty that his days might last } \\
\text { for ever, his sword be ever sharp, and his enemies be confounded. That they } \\
\text { might turn into black earth and be eaten by worms. }\end{array}$ \\
\hline $\begin{array}{l}\text { Aslına Öz Çeviri } \\
\text { (Adıvar, 2013: 139) }\end{array}$ & Oyun eski oyundu ve her vakit Padişah'ın ömrüne dua ile başlar, dua ile biterdi. \\
\hline
\end{tabular}

Tablo 1: Dini göstergelerin aktarılması I

İlk örnekte anlatının başkarakteri Rabia'nın babası, orta oyuncu Tevfik konu edilmektedir. Tevfik'in oyunlarına padişaha dua ederek başladığı, padişahla ters düşeceği işlere kalkışmadığı vurgulanmaktadır. Özde çeviride padişaha edilen duanın içeriği açıklanarak "Onun gösterileri Padişaha dua edilerek başlardı; ömrü uzun olsun, kılıcı keskin olsun, düşmanları yerle bir olsun ki toprak olup solucanlara yem olsunlar6" olarak aktarılmıştır. Padişahlıkla yönetilen Osmanlı Devleti'nde padişaha edilen duanın içeriğini İngiliz okurun tahmin edebilmesi beklenmediğinden Adıvar'ın ilk olarak zihninde Türkçe olarak padişaha o dönemlerde nasıl dua edildiğini canlandırdığı ve zihninde oluşturduğu bu duaları İngilizceye çevirerek İngiliz okura aktarmaya çalıştığı görülmektedir. Birinci örnekte Adıvar'ın İngiliz okurun kavram dünyasında olmayan padişaha yönelik duayı, zihinsel çeviri eylemine başvurarak anlaşılır kılmaya çalıştığı açıktır ve eserin özde çeviri

Aksi belirtilmedikçe vurgular tarafımıza aittir.

Aksi belirtilmedikçe çeviriler tarafımızca yapılmıştır.

Adres $\mid$ Address

RumeliDE Dil ve Edebiyat Araştırmaları Dergisi $\quad$ RumeliDE Journal of Language and Literature Studies Osmanağa Mahallesi, Mürver Çiçeği Sokak, No:14/8 Osmanağa Mahallesi, Mürver Çiçeği Sokak, No:14/8

Kadıköy - İSTANBUL / TÜRKIYE 34714 Kadıköy - ISTANBUL / TURKEY 34714 e-posta: editor@rumelide.com

tel: +90 505 7958124, +90 2167730616 phone: +90 505 7958124, +90 2167730616 
olduğunu kanıtlar niteliktedir. Aynı söylemin Türk okur için yapılan aslına öz çeviride nasıl

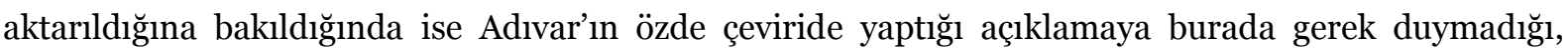
“Padişah’ın ömrüne dua ile başlar, dua ile biterdi...” diyerek aktardığı ve bu duanın içeriğine değinmediği görülmektedir. Bunun sebebinin ise Adıvar’ın Türk okurun bir padişaha edilecek duaları tahmin edebileceğini, kendi kültür ve kavram dünyalarından olan bu örneği açıklama olmaksızın anlayabileceğini düşündüğünden kaynaklandığı söylenebilir. Dolayısıyla aslına öz çeviride, özde çevirideki zihinsel çeviri işleminin silindiği görülmektedir.

\section{2. Örnek}

\begin{tabular}{|l|l|}
\hline $\begin{array}{l}\text { Inceleme } \\
\text { Metinleri }\end{array}$ & \multicolumn{1}{c|}{ İncelenen Bağlam } \\
\hline $\begin{array}{l}\text { Özde Çeviri } \\
\text { (Adıvar, 1935: 123) }\end{array}$ & $\begin{array}{l}\text { In her heart, however, she was thinking that she would make it up with him at Bairam, } \\
\text { when the Moslems forgive one another. She liked him. }\end{array}$ \\
\hline $\begin{array}{l}\text { Aslina Öz Çeviri } \\
\text { (Adıvar, 2013) }\end{array}$ & --- \\
\hline
\end{tabular}

Tablo 2: Dini göstergelerin aktarılması II

Dini göstergeler başlığı altında ele alınan ikinci örnekte Rabia ile arkadaşı Bilal'in arası bozuktur ve bu duruma içten içe üzülen Rabia, bayramda barışacaklarını ummaktadır. Çünkü dönemin toplumunda Müslümanlar bayramda birbiriyle küs kalmaz, tüm küsler barışır anlayışı hâkimdir. Bu anlayışı bilmeyen İngiliz okur için Adıvar'ın zihinsel çeviriye başvurarak Rabia'nın içinden geçenleri "Yine de kendi kendine Müslümanların birbirini affettiği Bayram gününde barışacaklarını söylüyordu. Ondan hoşlanmıştı.” olarak aktardığı görülmektedir. Özde çeviri metinde böyle bir detayın verilmiş olması, Adıvar'ın kendi değerlerini yabancılara aktarmak istemesinden kaynaklanabileceği gibi İngiliz okurun yabancı olduğu bu inançla ilgilerini daha çok çekmek istemesinden de kaynaklanıyor olabilir. Türk okur için yaptığı aslına öz çeviride ise anlatının bir özde çeviri olduğunu belli eden bu detayı ekleme gereği duymadığı görülmektedir.

\subsection{Deyim ve deyişlerin aktarılması}

Anlatılar incelendiğinde Adıvar’ın Türkçe deyim ve deyişleri sıklıkla iki anlatıda da kullandığı tespit edilmiş, bu sebepten deyim ve deyişlerin incelendiği ayrı bir başlık açılmıştır. Aşağıdaki iki örnekte Türkçe deyim ve deyişler özde çeviride ile aslına öz çeviride karşılaştırmalı olarak incelenmiştir.

\section{3. Örnek}

\begin{tabular}{|l|l|}
\hline $\begin{array}{l}\text { İnceleme } \\
\text { Metinleri }\end{array}$ & \multicolumn{1}{c|}{ İncelenen Bağlam } \\
\hline $\begin{array}{l}\text { Özde Çeviri } \\
\text { (Adıvar,1935: 259) }\end{array}$ & $\begin{array}{l}\text { "May Allah make you live long! I have heard of your loss" said the dwarf, } \\
\text { repeating the traditional sentence of Moslem condolence. }\end{array}$ \\
\hline $\begin{array}{l}\text { Aslına Öz Çeviri } \\
\text { (Adıvar, 2013: 253) }\end{array}$ & "Allah sana ömür versin, kusura bakma başın sağolsun demeyi unuttum". \\
\hline
\end{tabular}


Tablo 3: Deyim ve deyişlerin aktarılması I

Anlatının önemli karakterlerinden olan Peregrini'nin İtalya'da yaşayan annesi vefat etmiştir ve Rabia'nın amcası Rakım, Peregrini’ye başsağlığı dilemektedir. Özde çeviride Adıvar bu söylemi “Allah sana uzun ömürler versin! Vefat haberini aldım, dedi cüce Rakım o bilindik Müslüman taziye cümlesini tekrarlayarak” olarak aktarır. Türkçede birisi bir yakınını kaybettiğinde söylenen kalıplaşmış söz öbeğini Adıvar’ı bahsi geçen bağlama uygunluğu dolayısıyla zihninde tasarladığı ve "Allah sana ömür versin” söylemini birebir olarak İngilizceye çevirerek aktarmaya çalıştı̆̆ı gözlemlenmektedir. "Başın sağolsun" deyimini aktarırken ise İngilizlerin ilgili bağlamda sıkça kullandıkları "I have heard your loss" söylemini kullanmayı tercih etmiştir. Adıvar'ın aynı zamanda bu çeviri kararlarıyla yetinmeyip "Müslümanların taziye için kullandıkları geleneksel cümleleri" söylemini ekleyerek bu deyimlerin Türkler tarafından vefat haberlerinde kullanılan söylemler olduğunu bilmeyen İngiliz okur için ek bir bilgilendirme yapmış olur. Bu açıklama dahi Adıvar'ın bir özde çeviri ortaya koyduğunun göstergesi sayılabilir. Aslına öz çeviriye bakıldığında ise anlatı özüne döndüğünden ve Türk okur söz konusu deyim ve söylemlerin kullanıldı ̆̆ı bağlamı gayet iyi bildiğinden herhangi bir açıklamaya gerek duymamıştır. Okur farklılıklarının bir kez daha Adıvar'ın çeviri kararlarını şekillendirdiği görülmektedir.

\section{4. Örnek}

\begin{tabular}{|c|c|}
\hline $\begin{array}{l}\text { İnceleme } \\
\text { Metinleri }\end{array}$ & İncelenen Bağlam \\
\hline $\begin{array}{l}\text { Özde Çeviri } \\
\text { (Adıvar, 1935: 265) }\end{array}$ & $\begin{array}{l}\text { With a fatalistic gesture she shrugged her shoulders, and her forefinger passed over } \\
\text { her forehead. } \\
\text { "I shall have to read whatever is written there." }\end{array}$ \\
\hline $\begin{array}{l}\text { Aslına Öz Çeviri } \\
\text { (Adıvar, 2013: 262) }\end{array}$ & $\begin{array}{l}\text { Şahadet parmağı alnının üstünde dolaştı: } \\
\text { "Burada ne yazıldıysa onu göreceğim. Ne söylesen boş!" }\end{array}$ \\
\hline
\end{tabular}

Tablo 4: Deyim ve deyişlerin aktarılması II

Dördüncü örnekte Adıvar, kendi kültüründe oldukça önem atfedilen kader kavramına gönderme yapmaktadır. İncelenen bağlamda Rabia Türkçe yazgı, kader anlamına gelen "alın yazısı" söz öbeğini metaforik olarak canlandırmaktadır. Adıvar bu sahneyi özde çeviride "Kaderci bir yaklaşımla omuzlarını silkti, işaret parmağını alnında gezdirdi. Burada ne yazıldıysa onu yaşayacağım dedi." biçiminde aktarır. Görüleceği üzere Adıvar, İngiliz okurun kendi kavram dünyalarında olmayan alın yazısı kavramını anlayamayacaklarını düşünerek "kaderci bir yaklaşımla" söylemini özde çevirisine eklemiştir. Adıvar, eklemeyi yapmadığı takdirde bir İngiliz okurun "alnını göstererek burada ne yazıldıysa onu yaşayacağım" anlamına gelen "I shall have to read whatever is written there" cümlesini okuduğunda "alın yazısı" kavramına gönderme yapıldığını kavrayamayacağını bildiğinden, buradaki söylemlerin kaderci yaklaşıma işaret ettiğini İngiliz okurla açıkça paylaşır. Bu örnek de anlatının biz özde çeviri olduğunu kanıtlar niteliktedir. Adıvar’ın, aslına dönen anlatıda ise Türk halkı içine doğduğu kültür dolayısıyla kader ya da yazgı kavramlarına aşina olduğundan ve "alın yazısı" kavramını ve metaforik göndermelerini de kolayca anlayacaklarından "kaderci bir yaklaşımla" söylemini aslına öz çevirisinde verme gereği duymadığı görülmektedir.

\footnotetext{
Adres Address

RumeliDE Dil ve Edebiyat Araşttrmalar Dergisi $\quad$ RumeliDE Journal of Language and Literature Studies Osmanağa Mahallesi, Mürver Çiçeği Sokak, No:14/8 Osmanağa Mahallesi, Mürver Çiçeği Sokak, No:14/8 Kadıköy - İSTANBUL / TÜRKIYE 34714 Kadıköy - ISTANBUL / TURKEY 34714 e-posta: editor@rumelide.com e-mail: editor@rumelide.com, tel: +90 505 7958124, +90 2167730616 phone: +90 505 7958124, +90 2167730616
} 


\subsection{Yerel sanata dair göstergelerin aktarılması}

Anlatıların baş karakterlerinden Tevfik’in bir orta oyuncu ve bir karagöz oynatıcısı olduğu, baş karakter Rabia'nın ise musiki dersleri aldığı göz önünde bulundurulduğunda anlatıların yerel sanatla örülü olduğu açıkça ortadadır. Aşağıda Türk musikisine ve gösteri sanatlarına yönelik iki örnek, özde çeviri ve aslına öz çeviri karşılaştırılarak incelenmiştir.

\section{5. Örnek}

\begin{tabular}{|l|l|}
\hline $\begin{array}{l}\text { İnceleme } \\
\text { Metinleri }\end{array}$ & \multicolumn{1}{c|}{ İncelenen Bağlam } \\
\hline $\begin{array}{l}\text { Özde Çeviri } \\
\text { (Adıvar, 1935: 253) }\end{array}$ & $\begin{array}{l}\text {...and she sang the old, old song of “The Kerchief." } \\
\text { "From garden to garden wave thy kerchief ... the crimson kerchief, the } \\
\text { purple kerchief..." }\end{array}$ \\
\hline $\begin{array}{l}\text { Aslına Öz Çeviri } \\
\text { (Adıvar, 2013: 245) }\end{array}$ & $\begin{array}{l}\text { "Yemenim turalıdır" şarkısını söylemeye başladı. } \\
\text { "Allı yemenim, morlu yemenim, bir bahçeden bir bahçeye salla yemenim!” }\end{array}$ \\
\hline
\end{tabular}

Tablo 5: Yerel sanata dair göstergelerin aktarılması I

Yukarıdaki örnekte Rabia şarkı söylemekte, Peregrini, Vehbi Efendi ve Tevfik ise Rabia'yı dinlemektedirler. Söz konusu parçanın Münir Nurettin Selçuk'un Türk Sanat Musikisi türünde bir eseri olan "Allı Yemenim" adlı şarkısı olduğu görülmektedir. "Allı Yemenim" başlıklı şarkıyı Adıvar özde çevirisinde İngilizce başörtüsü ve mendil anlamlarına gelebilen "Kerchief" göstergesi ile aktarmaya çalışır, al renkli anlamına gelen ve yemeninin kırmızı renkli olduğunu belirten "allı" göstergesini özde çevirisinde verme gereği duymaz. Adıvar'ın Rabia’ya şarkı söyletirken bu şarkıyı ve sözlerini Türkçe olarak zihninde tasarladığı ve İngilizceye çevirdiği aşikardır. Yalnızca şarkının adı değil, sözlerinin çevirisi de bu durumu kanıtlar niteliktedir. Özde çeviride bu sahne "O eski şarkıyı söyledi, "Eşarp” şarkısını. Bahçeden bahçeye salla eşarbını... Kırmızı eşarbını, mor eşarbını...” olarak aktarılır ve Adıvar'ın başlıkta vermediği "kırmızı, al” göstergesini Türkçe şarkı sözlerinde olmamasına rağmen ekleyerek İngiliz okura yansıtmaya çalıştığı gözlemlenmektedir. Adıvar'ın İngilizce metinde yalnızca Rabia'nın şarkı söylediğini okurla paylaşıp şarkının içeriğine ve sözlerine değinmesine gerek olmadığı halde, dönemin ünlü parçalarından olan ve kendisinin de çocukken dinlediği ve bildiği (Enginün, 2000: 163) bu parçayı zihinsel çeviri sürecinden geçirerek İngiliz okurla paylaştığı ve bir özde çeviri ortaya koyduğu görülmektedir. Aslına öz çeviriye bakıldığında ise "Allı Yemenim" şarkısının sözlerini olduğu şekilde çevirisine eklediğini ancak şarkının adında değişikliğe giderek "Yemenim Turalıdır" başlığı ile vermesi oldukça ilginçtir. Adıvar’ın İngilizce özde çevirisini Türk okur için aslına döndürürken parçanın adını dönemin diğer bir ünlü şarkılarından olan "Yemenim Turalıdır” parçası ile karıştırmış olabileceği düşünülmektedir.

\section{6. Örnek}

\begin{tabular}{|c|c|}
\hline $\begin{array}{l}\text { İnceleme } \\
\text { Metinleri }\end{array}$ & İncelenen Bağlam \\
\hline $\begin{array}{l}\text { Özde Çeviri } \\
\text { (Adıvar, 1935: 76) }\end{array}$ & $\begin{array}{l}\text { The cardboard figures for the shadow-play were ready also. The three of them, after } \\
\text { consulting together, selected the part of the garden across which the curtain } \\
\text { was to be stretched, and the part where the mats were to be spread on the } \\
\text { ground, with a few stools as front seats for the quality. }\end{array}$ \\
\hline
\end{tabular}




\section{Aslına Öz Çeviri Tevfik’in Karagöz takımı da hazırdı. Üçler, bahçede perde yerini, (Adıvar, 2013: 79) fener yerini tespit ettiler.}

Tablo 6: Yerel sanata dair göstergelerin aktarılması II

Osmanlı’nın yerel sanat dallarından gölge oyununun anlatıldığı 6. örnekte Rabia, Tevfik ve Rakım Ramazan gecesinde gölge oyunu oynatmak için hazırlık yapmaktadırlar. Geleneksel Türk seyirlik oyunlarından olan gölge oyunu yani halk arasında bilinen adıyla Karagöz oyunları, Osmanlı Dönemi’nde gerek saray çevresindeki kişiler için gerekse halk için oynatılmıştır. Bu örnekte de bir Ramazan gecesinde Tevfik ve ekibi halkı eğlendirmek için Karagöz oyunu düzenlemektedir. İngiliz okurun kavram dünyalarında bulunmayan ve hiç bilmedikleri gölge oyunu ile onları tanıştırması gereken Adıvar, özde çeviride bu söylemi "Gölge oyunu için karton figürler hazırdı. Üçü birlikte karar almış, bahçede perdenin nereye gerileceğine, minderlerin ve kaliteli gözükmesi adına ön koltuk olarak taburelerin nerelere konulacağına karar vermişlerdi." olarak aktarır. Adıvar'ın bu söylemde öncelikle İngiliz okur için gölge oyununun ne olduğu ve nasıl bir ortamda oynandığına dair detayları içeren bir sahne canlandırdığı ve bu sahneyi İngilizceye çevirdiği açıktır. Öyle ki, Adıvar özde çevirisinde gölge oyununun karton figürler üzerinden gerçekleştirildiğine, bir perde gerilerek bu karakterlerin oynatıldığına ve seyircilerin ise çoğunun yerde kimilerinin ise taburede ön siradan gösteriyi izleyebildiğine vurgu yapar. Adıvar, bu söylemi çıkış kültürü olan Türk okur için aslına döndürdüğündeyse gölge oyununda kartondan figürlerin varlığını halihazırda bildiklerinden "karagöz takımı" diyerek materyallerin asıl adını kullanır. Aynı zamanda Türk okur perdenin gerilmesi gerektiğini de bildiğinden o detayı da aslına öz çevirisinden çlkararak yalnızca perdenin ve fenerin yerini tespit ettiklerini söyler. Adıvar bu örnekte de metni aslına döndürürken özde çeviri olduğuna dair kanıt olabilecek kısımları çevirisinden çıkarmıştır.

\subsection{Toplumsal yaşama dair göstergelerin aktarılması}

Anlatılar Osmanlı Devleti'nin son yıllarında gerek İstanbul'un arka mahallelerindeki halkın gerekse saray ve konak eşrafının hayatlarını içermekte ve her iki kesimin yaşantısından da örnekler sunmaktadır. Aşağıdaki iki örnekte özde çeviri ve aslına öz çeviri karşılaştııllarak incelenmiştir.

\section{7. Örnek}

\begin{tabular}{|c|c|}
\hline $\begin{array}{l}\text { İnceleme } \\
\text { Metinleri }\end{array}$ & İncelenen Bağlam \\
\hline $\begin{array}{l}\text { Özde Çeviri } \\
\text { (Adıvar, 1935: 38) }\end{array}$ & $\begin{array}{l}\text { On the circular divan stretching along the four walls of the reception-room an audience } \\
\text { of white-veiled ladies sat in rows, their feet tucked under their bodies, their } \\
\text { eyes devoutly bent on their knees, their fingers telling their rosaries. Their } \\
\text { lips moved, repeating divine attributes without emitting any sound, and as they } \\
\text { swung gently in tune to Rabia's chanting they were like an assembly of Eastern } \\
\text { nuns at their prayers. }\end{array}$ \\
\hline $\begin{array}{l}\text { Aslına Öz Çeviri } \\
\text { (Adıvar, 2013: 38) }\end{array}$ & $\begin{array}{l}\text { Çepçevre sedirlerin üstüne sıra sıra ihtiyar kadınlar dizilmiş. Başlarında beyaz } \\
\text { namaz bezleri, buruşuk yüzleri mütekallis, gözleri vecd içinde... Ellerinde } \\
\text { rengârenk tespihler, parmakları hareket ediyor, soluk dudakları kımıldıyor, } \\
\text { yandan yana hafif hafif vücutları dalgalanıyor. }\end{array}$ \\
\hline
\end{tabular}

Tablo 7: Toplumsal yaşama dair göstergelerin aktarılması I

Adres

RumeliDE Dil ve Edebiyat Araştırmaları Dergisi Osmanağa Mahallesi, Mürver Ciçeği Sokak, No:14/8 Kadıköy - ISTANBUL / TÜRKIYE 34714 e-posta: editor@rumelide.com tel: +90 505 7958124, +90 2167730616
Address

RumeliDE Journal of Language and Literature Studies Osmanağa Mahallesi, Mürver Çiçeği Sokak, No:14/8

Kadıköy - ISTANBUL / TURKEY 34714

e-mail: editor@rumelide.com,

phone: +90 505 7958124, +90 2167730616 
Yedinci örnekte Sabiha Hanım'ın konağında gerçekleştirdiği kandil kutlaması okurla paylaşılmakta, kandil gecesinde konağa davet edilen kadınların kutlama esnasında yaptıkları detaylı bir şekilde anlatılmaktadır. Özde çeviride Adıvar bu sahneyi "Kabul odasının dört duvarı boyunca uzanan yuvarlak divanın üzerinde sıra sıra dizilmiş, beyaz örtülü kadınlardan oluşan bir topluluk oturuyordu, dizlerinin üzerinde, huşu içinde önlerine bakıyorlar, bir yandan tespih çekiyorlardı. Hepsinin dudakları kımıldıyor, ilahi nitelikte sesler çıkarıyorlar ve Rabia'nın ilahisine göre ritim tutturarak nazikçe sallandıklarında, sanki dua eden Doğulu rahibeler topluluğu gibi gözüküyorlardı.” olarak aktarmıştır. Görüleceği üzere Adıvar kandil gecesinde, o dönemlerde bir sarayda ya da konakta gerçekleşebilmesi muhtemel bir kutlamayı ilk olarak zihninde canlandırmış, akabinde zihninde canlandırdığı bu sahneyi İngilizceye çevirerek İngiliz okura aktarmıştır. Adıvar böyle bir törenden habersiz olan İngiliz okurun da zihninde bu sahneyi canlandırabilmesi için oldukça detaylı bir anlatım gerçekleştirerek kandil gününde mevlit dinlemek için gelen kadınların beyaz bir örtü taktığından, konakta her birinin ellerinde tespihleriyle aynı şekilde oturup mevlidin melodisine ayak uyduracak şekilde eş zamanlı sallandıklarından bahsetmiştir. Adıvar, bu sahneyi İngiliz okurun tam olarak anlamaması ihtimaline karşı da kandil gecesi yapılan bu kutlamayı "Doğulu rahibelerin ayini” olarak nitelendirebileceklerini söylemiş ve ötekinin yani İngiliz okurun kendilerinde olan bir değerle bağlantı kurarak anlamalarını sağlamaya çalışmıştır. Tüm bu göstergelerin öncelikle Türkçe olarak tasarlanıp sonrasında zihinsel bir çeviri sürecinden geçirilerek İngilizceye aktarıldı̆̆ı açıktır. Söz konusu göstergelerin bu türden törenlere alışkın olan Türk okuru için gerçekleştirilen çeviride nasıl aslına döndüğüne bakıldığında ise, Adıvar'ın özde çevirideki kadar detaylı olmasa da burada da kandil gecesi kutlamasında davetli kadınların yaptıklarını anlattığı gözlemlenmiştir. Ancak Adıvar, İngiliz okurun kendileriyle bağ kurarak anlamalarını kolaylaştırması amacıyla eklediği rahibe benzetmesini bir işlevi olmayacağından aslına öz çevirisinden çıkarmıştır.

\section{8. Örnek}

\begin{tabular}{|l|l|}
\hline $\begin{array}{l}\text { Inceleme } \\
\text { Metinleri }\end{array}$ & \multicolumn{1}{c|}{ Incelenen Bağlam } \\
\hline $\begin{array}{l}\text { Özde Çeviri } \\
\text { (Adıvar, 1935: 271) }\end{array}$ & $\begin{array}{l}\text { "Listen, Rabia, in August it is the thirty-second anniversary of the Sultan's } \\
\text { accession to the throne. There will be an amnesty of a sort. I'll try to get as many of } \\
\text { the Damascus exiles as I can on the list." }\end{array}$ \\
\hline $\begin{array}{l}\text { Aslına Öz Çeviri } \\
\text { (Adıvar, 2013: 268) }\end{array}$ & \begin{tabular}{l} 
"Cülûsta mutlak babanı getirtirim, Rabia. Düğününden evvel olmasını isterdim ama... \\
\hline
\end{tabular} \\
\hline
\end{tabular}

Tablo 8: Toplumsal yaşama dair göstergelerin aktarılması II

Sekizinci örnekte Zaptiye Nazırı Selim Paşa, Rabia’ya sürgünde olan babasını Rabia’nın düğününe dek yurda getirebilme ihtimalinden bahsetmektedir. Adıvar özde çevirisinde bu durumu "Dinle Rabia, ağustos ayı Padişah'ın tahta çıkışının 32. Yıl dönümünü olacak, bu sebeple bir çeşit af çıkacak. Ben de Şam'da sürgünde olanların çoğunu getirmeye çalışacağım.” olarak verir. Görüldüğü üzere özde çeviride İngiliz okur için padişahların tahta çıkışlarının kutlandığı cülus günlerinde bir çeşit af gerçekleştirildiği ve sürgündekilerin yurda getirildiği detaylıca açıklanmıştır. Aslına öz çeviride ise yalnızca "cülusta mutlak babanı getirtirim...” olarak aktarılır, çünkü Türk okurun cülus zamanı padişahların tahta çıkış yıldönümleri olduğunu ve o günlerin bayram gibi kutlandığını, halka gerek bahşiş gerek af gibi iyiliklerin yapıldığını bildiği düşünülmektedir. Adıvar İngilizlerin kavram dünyasında olmayan "cülus"

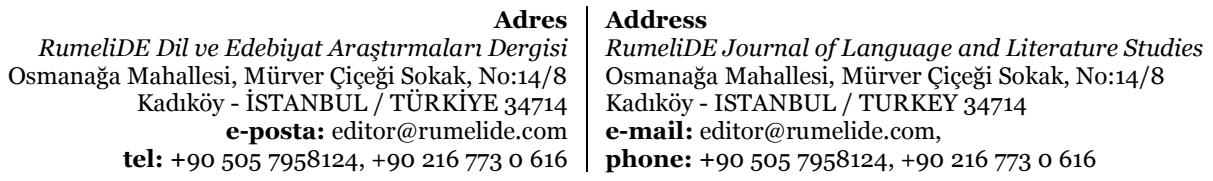


göstergesini özde çevirisine eklediği açlklamalarla anlaşlır kılmaya çalışmıştır, metin aslına döndüğündeyse Türk halkı bu göstergeyi ve anlamını zaten bildiğinden özde çevirideki açıklamaları aslına öz çevirisinden çıkarmıştır.

\subsection{Giyim kuşama dair göstergelerin aktarılması}

Osmanlı dönemine ait giyim kuşam da anlatıda sıkça yer almaktadır. Aşağıdaki örnekte döneme özgü bir aksesuar olan "hotoz" özde çeviride ve aslına öz çeviride karşılaştırmalı olarak incelenmiştir.

\section{9. Örnek}

\begin{tabular}{|l|l|}
\hline $\begin{array}{l}\text { İnceleme } \\
\text { Metinleri }\end{array}$ & \multicolumn{1}{c|}{ İncelenen Bağlam } \\
\hline $\begin{array}{l}\text { Özde Çeviri } \\
\text { (Adıvar, 1935: 50) }\end{array}$ & $\begin{array}{l}\text { All wore long robes and carried trains thrown negligently over their left arms. They also } \\
\text { wore tiny headdresses made of flimsy, gauzy stuff and perilously perched over one } \\
\text { ear. }\end{array}$ \\
\hline $\begin{array}{l}\text { Aslına Öz Çeviri } \\
\text { (Adıvar, 2013: 54) }\end{array}$ & $\begin{array}{l}\text { Hepsi uzun eteklerini sol kollarının üstüne atmıslar, hepsinin başında hemen kayacakmış } \\
\text { gibi sol kulaklarına tehlikeli surette yıkllan bir hotoz... }\end{array}$ \\
\hline
\end{tabular}

Tablo 9: Giyim kuşama dair göstergelerin aktarılması

Sabiha Hanım konağında ziyafet vermektedir ve bu ziyafet esnasında Rabia'nın geleneksel Osmanlı kıyafetleri giymiş olan cariyelerin şaşalı kıyafetleri karşısında ne kadar şaşırdığı anlatılmaktadır. Adıvar, cariyelerin giydiği kıyafetleri betimlerken özde çevirisinde "Her biri uzun elbiseler giyiyordu ve elbiselerinin kuyruklarını gelişigüzel şekilde sol omuzlarına atmışlardı. Tiril tiril ince tülden yapılmış küçük başlıklar takıyorlardı, o da tehlikeli bir şekilde tek kulaklarına düşüyordu.” söylemini kullanır. Burada Adıvar'ın İngiliz okurun anlamakta güçlük çekeceği, kendi kültürlerinde bulunmayan "hotoz" göstergesini aktarırken zorlandığı ve zihinsel çeviri işlemine başvurduğu görülmektedir. Kadınların süs için saçlarının üstüne taktıkları, çeşitli renk ve biçimde yapılmış küçük başlık7 olarak tanımlanmakta olan hotoz Osmanlı Dönemi’nde kadınlar tarafından sıklıkla kullanılan bir aksesuardır. Kavram dünyalarında hotoz bulunmayan İngiliz okur için Adıvar bu göstergeyi detaylı bir şekilde İngilizceye çevirerek aktarmış ve bir özde çeviri ortaya koymuştur. Bir saç aksesuarı olan hotozu İngiliz okura anlatabilmek adına özde çevirisine "tiril tiril ince tülden yapılmış küçük başlıklar" betimlemesini ekleyen Adıvar, bunun bir başlık olduğunu ve ipek, ince tül gibi tiril tiril malzemelerden yapılan ve tamamen süs için kullanılan bir aksesuar olduğunu açıllamaya çalışmıştır. Aslına öz çeviride ise özde çevirideki tüm bu detayları çıkarmış ve o dönemlerde hotozu bilmesi beklenen Türk okur için yalnızca "hotoz" göstergesini kullanarak aktarmıştır.

\subsection{Yemek kültürüne dair göstergelerin aktarılması}

Türk mutfağına ait yöresel yemekler de Adıvar'ın özde çeviriye başvurmak durumunda kaldığı bir diğer kültürel gösterge alt kategorisidir. Aşağıdaki örnekte yemeklerin özde çeviride ve aslına öz çeviride nasıl aktarıldığı karşılaştırılarak incelenmiştir.

Türk Dil Kurumu. https://sozluk.gov.tr. [20.01.2021] 


\section{0. Örnek}

\begin{tabular}{|l|l|}
\hline $\begin{array}{l}\text { İnceleme } \\
\text { Metinleri }\end{array}$ & \multicolumn{1}{c|}{ İncelenen Bağlam } \\
\hline $\begin{array}{l}\text { Özde Çeviri } \\
\text { (Adıvar, 1935: 204) }\end{array}$ & $\begin{array}{l}\text { "I've brought stuffed vine-leaves and rose-petal jam, Tewfik. The basket is full of } \\
\text { meat, bread, cheese.” }\end{array}$ \\
\hline $\begin{array}{l}\text { Aslına Öz Çeviri } \\
\text { (Adıvar, 2013: 191) }\end{array}$ & $\begin{array}{l}\text { Rakım'ın terleyerek sürüklediği sepetleri yerleştirdi. } \\
\text { "Dolma var, zeytin, peynir, söğüş var... Şam’a gidince bize yaz.” }\end{array}$ \\
\hline
\end{tabular}

Tablo 10: Yemek kültürüne dair göstergelerin aktarılması

Padişah tarafından sürgüne gönderilen Tevfik'e gemide yolluk yapması için kızı Rabia içi yiyecek dolu bir sepet getirir. Özde çeviride bu yiyecekler "Sana doldurulmuş üzüm yaprağı, gül yaprağı reçeli getirdim Tevfik. Sepetin içi et, ekmek ve peynir dolu.” olarak aktarır. Adıvar’ın "doldurulmuş üzüm yaprağı" olarak nitelendirdiği yiyeceğin geleneksel Türk yemeklerinden "sarma" olduğu, "gül yaprağı reçeli" olarak açıkladığı yiyeceğin ise yine geleneksel Türk reçellerinden "gül reçeli" olduğu görülmektedir. Adıvar'ın öncelikle Rabia'nın sürgüne giden babasına ne tür yiyecekler götürebileceğini zihninde tasarladığı ve bu geleneksel yemekleri İngilizceye çevirerek eserine aktardığı, dolayısıyla bir özde çeviri ortaya koyduğu açıktır. Sarma göstergesi kendi kavram dünyalarında bulunmayan İngiliz okur için bir şey ifade etmeyeceğinden Adıvar yaptığı açıklama ile sarmanın üzüm yaprağının doldurulmuş ve pişirilmiş hali olduğunu onlarla paylaşmıştır. Aslına öz çeviride ise Türk okurun zaten aşina olduğu bu yiyeceklerde herhangi bir açımlama yoluna gitmemiştir.

\section{Sonuç}

Bu çalışmada incelenen örnekler neticesinde Adıvar'ın kendi kültürüne dair göstergelerle örülü eserini İngilizce olarak kaleme alırken ister istemez zihinsel bir çeviri sürecinden geçirdiği varsayımı doğrulanmış, bir “özde çeviri” (Öztürk Kasar, 2012) ortaya koyduğu görülmüştür. The Clown and His Daughter her ne kadar özgün bir eser gibi sunulmuş olsa da "sözde özgün”, "özde çeviri” (Öztürk Kasar 2020: 6) bir eserdir. The Clown and His Daughter'ın Türkçe çevirisi olan ve Adıvar tarafından çevirisi gerçekleştirilen Sinekli Bakkal ise hem Öztürk Kasar’ın "aslına çeviri” kavramına hem de "öz çeviri” kavramına uyduğundan bu çalışmada "aslına öz çeviri” olarak kavramsallaştırılmış ve "aslına çeviri”nin farklı bir türü olarak değerlendirilmiştir.

Öz bağlamdan yabancı bağlama giden bir özde çeviri olarak incelenen The Clown and His Daughter'da, Adıvar'ın içine doğduğu ve büyüdüğü Osmanlı kültürüne dair öğeleri İngiliz okur için aktarırken dönemin atmosferini olabildiğince gerçekçi bir şekilde yansıtmaya çalıştığı, hedef kitlesinin daha kolay anlaması için uyarlama yoluna gitmediği görülmüştür. Bu şekilde okuru kendi kültürüne yönelik bir araştırma yapmaya sevk etme amacı gütmüş olabileceği düşünülmektedir. Bu doğrultuda, incelenen örneklerdeki çeviri kararlarından yola çıkarak bir özde çevirmen olarak Adıvar'ın kendi kültürünü koruma ve "öteki”ne tanıtma arzusunda olduğu çıkarımı yapılabilir. İncelenen çeviri kararlarından hareketle Adıvar'ın hedef kitlesinin yabancısı olduğu ve İngilizcede de karşllığı bulunmayan, kendi kültürüne dair olgu ve olayları çevirisine açıklama yoluyla kattığı söylenebilir.

Diğer yandan aslına öz çeviride Adıvar, ilk olarak zihinsel bir çeviri sürecinden geçirerek İngilizceye aktardığı kendi kültürüne ait göstergeleri bu kez hareket noktasına, yani aslına döndürmüştür. Okur

\begin{tabular}{r|l} 
Adres & Address \\
RumeliDE Dil ve Edebiyat Araştırmalar Dergisi & RumeliDE Journal of Language and Literature Studies \\
Osmanağa Mahallesi, Mürver Çiçeği Sokak, No:14/8 & Osmanağa Mahallesi, Mürver Çiçeği Sokak, No:14/8 \\
Kadıköy - İSTANBUL / TÜRKIYE 34714 & Kadıköy - ISTANBUL / TURKEY 34714 \\
e-posta: editor@rumelide.com & e-mail: editor@rumelide.com, \\
phone: +90 505 7958124, +90 2167730616
\end{tabular}


farklılıklarının çevirmen olarak Adıvar’ı ciddi boyutta yönlendirdiği söylenebilir. Adıvar'ın göstergeleri aslına döndürürken metne müdahale etmekten çekinmediği, İngiliz okur için eklediği açıklayıcı kısımları Türk okur için gerçekleştirdiği aslına öz çevirisinden çıkarma eğiliminde olduğu gözlemlenmiştir. Bu durumun Adıvar'ın bir öz çevirmen olmasından, yani kendi eserini çevirmesinden kaynaklandığı düşünülmektedir. Sinekli Bakkal'ın bir aslına öz çeviri olması onu diğer aslına çevirilerden ayırmaktadır. Öyle ki, Tuna (2020: 902), Alexander Dumas'ın Ali Pacha başlıklı eserini özde çeviri olarak ele aldığı makalesinde bu eseri, aslına çevirisi ve dolaylı özde çevirisi ile birlikte karşılaştırmalı olarak incelemiş ve aslına çeviriyi gerçekleştiren çevirmenin "Dumas'nın tarif etme yoluyla tanımlamaya çalıştığı her olgunun ve hatta nesnenin ne olduğunu saptama zorunluluğu" olduğunu belirtmiştir. Bu çalışmaya konu olan aslına öz çeviride ise özde çevirinin de aslına çevirinin de çevirmeni Adıvar olduğundan, Tuna'nın incelediği aslına çevirinin çevirmeni gibi zorluklarla karşılaşmamış, kendi özde çevirisini aslına döndürmüştür. Bu bağlamda, farklı çeviri türlerinin çevirmenden beklentileri de farklılaştırdığı göze çarpmaktadır.

Sonuç olarak Çeviri Göstergebilimi çerçevesinde gerçekleştirilen bu çalışmada, "özde çeviri” (Öztürk Kasar, 2012) kavramının getirdiği yeni bakış açısıyla İngiltere'de özgün metin olarak yayımlanmış bir eser olan The Clown and His Daughter'a çeviri ürün olarak yaklaşlabilmiştir. Gerçekleştirilen inceleme sonucunda elde edilen veriler, eserin bir çeviri ürün olduğunu kanttlar niteliktedir. Metin içi inceleme yoluyla çevirmenin zihinsel çeviri izlerinin gözlemlenebildiği The Clown and His Daughter başlıklı anlatı bir çeviri ürün olarak kabul edildiğinde, bu eserin Türkçe çevirisi olan Sinekli Bakkal'ın farklı bir çeviri türü olarak incelenmesi gerekmektedir. Bu bağlamda, "aslına çeviri" (Öztürk Kasar, 2012) kavramı Sinekli Bakkal'ın farklı türden bir çeviri olarak ele alınıp incelenmesine ve "aslına öz çeviri” olarak kavramlaştırılmasına olanak sağlamıştır. Söz konusu kavramlar sayesinde, iki çeviri ürünün de çevirmeni olarak Adıvar’ın farklı kavram dünyalarına sahip iki okur kitlesi için göstergeleri nassl dönüştürdüğü gözlemlenebilmiştir.

Çeviribilim alanında yeni kavramlara ihtiyaç duyulduğu, farklı vaka incelemeleriyle farklı çeviri türlerinin ortaya çıkarılabileceği söylenebilir. Bu doğrultuda, Çeviri Göstergebilimi yaklaşımıyla ortaya konmuş "özde çeviri”, "aslına çeviri” (Öztürk Kasar, 2012) kavramları Çeviribilim ve Göstergebilimin birbirinden beslenebileceğinin ve bu durumun alanda zenginleşmeyi beraberinde getireceğinin göstergesidir.

\section{Kaynakça}

Adivar, H. E. (1935). The clown and his daughter. London: George Allen \&Unwin.

Adıvar, H. E. (1936). Sinekli bakkal. İstanbul: Ahmet Halit Kitabevi.

Adıvar, H. E. (2013). Sinekli bakkal. İstanbul: Can.

Arslan, M. A. (2006). A comparative study on Halide Edip Adivar's The Clown and His Daughter as a Rewrite. (Yayımlanmamış yüksek lisans tezi). Dokuz Eylül Üniversitesi, İzmir.

Burian, O. (2004). Denemeler ve eleştiriler. Türkiye Bilimler Akademisi.

Grutman, R. (2009). Self-translation. The routledge encyclopedia of translation studies. Ed. Mona Baker and Gabriella Saldanha. USA; Canada: Routledge.

Çalışlar, İ. (2010). Halide Edib-Biyografisine sığmayan kadın. İstanbul: Everest.

Durakbaşa, A. (2009). Halide Edib Türk modernleşmesi ve feminizm. İstanbul: İletişim.

Enginün, İ. (1998). Halide Edip Adıvar. İstanbul: Toker.

Enginün, İ. (2007). Halide Edib Adıvar’n eserlerinde Doğu ve Batı meselesi. İstanbul: Dergâh.

\begin{tabular}{r|l} 
Adres & Address \\
RumeliDE Dil ve Edebiyat Araşttrmaları Dergisi & RumeliDE Journal of Language and Literature Studies \\
Osmanağa Mahallesi, Mürver Çiçeği Sokak, No:14/8 & Osmanağa Mahallesi, Mürver Çiçeği Sokak, No:14/8 \\
Kadıköy - ISTANBUL / TÜRKIYE 34714 & Kadıköy - ISTANBUL / TURKEY 34714 \\
e-posta: editor@rumelide.com & e-mail: editor@rumelide.com, \\
phone: +90 505 7958124, +90 2167730616
\end{tabular}


Moran, B. (1998). Türk romanına eleștirel bir bakış 1: Ahmet Mithat'tan Ahmet Hamdi Tanpınar'a. İstanbul: İletişim.

Öztürk Kasar, S. (2001). La sémiotique subjectale et la traduction. Third International Congress- Claims, Changes and Challenges in Translation Studies Abstracts, 30 Ağustos-1 Eylül 2001. Kopenhag: European Society for Translation, Copenhagen Business School. 24-25.

Öztürk Kasar, S. (2012). Traduction de la ville sous le point de vue sémiotique: Istanbul à travers ses signes en trois langues. In N. Rentel \& S. Schwerter (dir.), Défis et enjeux de la médiation interculturelle. Frankfurt am Main: Peter Lang, 267-285.

Öztürk Kasar, S. (2020). Çeviri göstergebilimi ile kent göstergebiliminin bütünleşik bağlamında özde çeviri kavramının incelenmesi. Dünya Dilleri, Edebiyatları ve Çeviri Çalışmaları Dergisi. 1(1), 1-25.

Öztürk Kasar, S. (2021). Traduire la ville en filigrane: Istanbul par Georges Simenon dans Les Clients d'Avrenos, Vous avez dit littérature belge francophone? Le défi de la traduction, Catherine Gravet et Katrien Lievois (éds.), Frankfurt, Peter Lang, 235-266.

Öztürk Kasar, S. \& Tuna, D. (2015). Yaşam, yazın ve yazın çevirisi için gösterge okuma. Frankofoni. 27: 457482.

Tuna, D. (2020). Yazarın zihninde bir çeviri edimi: özde çeviri ürünü olarak kaynak metin ve aslına çevirisi. RumeliDE Dil ve Edebiyat Araştırmaları Dergisi. 882-904.

Tuna, D. \& Çelik, B. (2021). From wiping out of the meaning to over-interpretation: the translator as covert co-author in the rewriting of Istanbul. Journal of Language and Linguistic Studies, 17 (Special Issue 2), 1083-1098.

Yalçındağ, S. \& Karadağ, A. B. (2020). Back and forth: The curious case of the translations of Halide Edib Adivar's The Clown and His Daughter. Translogos. 41-61.

RumeliDE Dil ve Edebiyat Araştırmaları Dergisi Osmanağa Mahallesi, Mürver Ciçeği Sokak, No:14/8 Kadıköy - İSTANBUL / TÜRKIYE 34714 e-posta: editor@rumelide.com tel: +90 505 7958124, +90 2167730616
Address

RumeliDE Journal of Language and Literature Studies Osmanağa Mahallesi, Mürver Çiçeği Sokak, No:14/8

Kadıköy - ISTANBUL / TURKEY 34714

e-mail: editor@rumelide.com,

phone: +90 $5057958124,+902167730616$ 